Tjalling C. Koopmans Research Institute Tplligh Aoopman

Discussion Paper Series nr: 05-01

\title{
The Part-Time Wage Penalty: a Career Perspective
}

Giovanni Russo Wolter Hassink 


\section{Tjalling C. Koopmans Research Institute Utrecht School of Economics \\ Utrecht University}

Vredenburg 138

3511 BG Utrecht

The Netherlands

telephone $\quad+31302539800$

fax $\quad+31302537373$

website www.koopmansinstitute.uu.nl

The Tjalling C. Koopmans Institute is the research institute and research school of Utrecht School of Economics.

It was founded in 2003, and named after Professor Tjalling C. Koopmans, Dutch-born Nobel Prize laureate in economics of 1975.

In the discussion papers series the Koopmans Institute publishes results of ongoing research for early dissemination of research results, and to enhance discussion with colleagues.

Please send any comments and suggestions on the Koopmans institute, or this series to M.Damhuis@econ.uu.nl

ontwerp voorblad: WRIK Utrecht

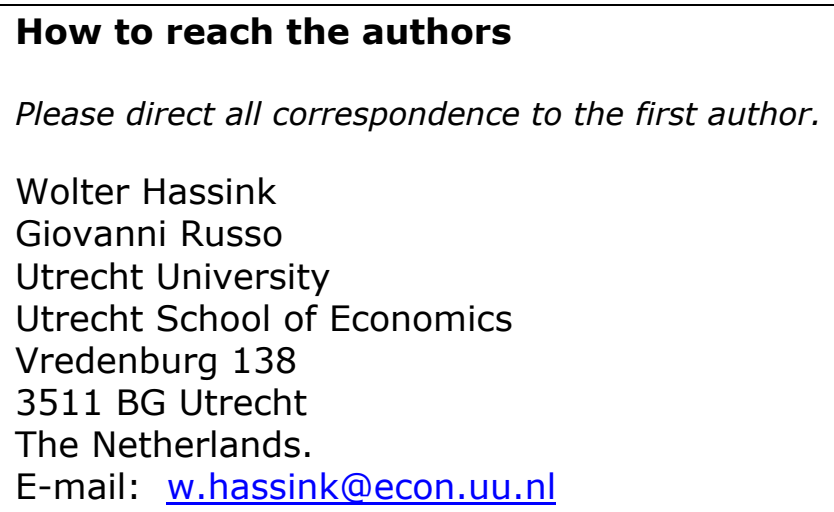


Utrecht School of Economics

Tjalling C. Koopmans Research Institute

Discussion Paper Series 05-01

\title{
The Part-Time Wage Penalty: a Career Perspective
}

\author{
Giovanni Russo \\ Wolter Hassink \\ Utrecht School of Economics \\ Utrecht University \\ January 2005
}

\begin{abstract}
Part-time employment has become an extremely popular work arrangement in the Netherlands because it renders employment compatible with non-work activities. We posit that there may be a downside to part-time employment, which is related to its negative effects on workers' career. This may be the case when firms use promotions to stimulate skill acquisition and human capital accumulation or when they base their work incentive schemes on performance measures that are affected by the number of hours worked or when they screen workers on the basis of the number of hours worked. Because promotions are an important source of wage growth, the low incidence of promotion among part-time workers may contribute to the emergence of the part-time wage penalty (i.e., the wage difference between a part-time worker and an otherwise equal full-time worker) in due time. Consistent with this view, we find that (male and female) workers in part-time jobs are characterized by a lower incidence of promotion relative to workers in full-time jobs and that promotions account for a wage growth of eight log points. Moreover, we find that the part-time wage penalty does not arise at the onset of a career as young workers join the labor market but that it tends to develop over time as labor market experience and the effect of missed promotions cumulate.
\end{abstract}

Keywords: Wages; Wage Gap; Part-Time Employment; Promotions

JEL classification: J31, J24, J22

\section{Acknowledgements}

We are grateful to the Dutch Ministry of Social Affairs and Employment for giving us access to the AVO-data 


\section{Introduction}

The introduction of flexible work arrangements, such as part-time employment, has facilitated the reconciliation between women's multiple roles in the household and in the labor market, leading to increased women labor market participation. ${ }^{1}$ In fact, women's participation in labor market activities is intimately connected to women's role within the household (Francine D. Blau, 1998; Francine D. Blau and Lawrence M. Kahn, 2003; OECD, 2002). ${ }^{2}$ Moreover, women in the labor market reportedly fare badly because they must combine labor market activities with family and fertility decisions; a trade-off which their male counterparts seldom face (Claudia D. Goldin, 1997; OECD, 2001). ${ }^{3}$ Part-time employment has quickly achieved extreme popularity among Dutch women of all age groups (Rob Euwals and Maurice Hogerbrugge, 2004). ${ }^{4}$ Workers (male and female) are usually happy with their part-time jobs because they regard them as the result of personal choices rather than as a failure to get a full-time job. ${ }^{5}$ However, part-time workers tend to receive lower wages ${ }^{6}$ than their full-time colleagues ceteris paribus. To this difference is referred to as the part-time wage penalty (the difference between the wage earned by otherwise equal parttime and full-time workers).

\footnotetext{
${ }^{1}$ The choice of part-time work can be related to the provision of childcare facilities; in $199242.5 \%$ of Dutch women put the lack of such facilities on top of the list of obstacles to work and to labor market participation in general. This happened in a period when Dutch women's labor market participation and human capital were steadily increasing (Ronald Schettkat and Lara Yocarini, 2001).

${ }^{2}$ Employers are aware of women's heterogeneity with respect to their role within the household. However, employers cannot tell, out of a group of otherwise equal women, who is going to spend time out of the labor market (and if so, how much). Therefore, firms (statistically) discriminate against the whole group, a behavior that, in turn, affects women's investment in human capital (Shelly J. Lundberg and Richard Startz, 1983). ${ }^{3}$ However, the extent of the gender wage gap has diminished over time as women have accumulated more human capital and women's presence on the labor market has become more and more customary (Francine D. Blau and Lawrence M. Kahn, 1997). Dutch women have, on average, 7 years of tenure against an average tenure of 10 years among male workers (quite constant during the 1990s). Furthermore, if anticipated, time out of the labor market affects occupational choice (and occupational segregation). Polacheck (1981) posits that females choose occupations in which the depreciation of human capital during time off the labor market is the slowest.

${ }^{4}$ The 1999 labor force survey shows that 69\% (18\%) of employed women (men) hold a part-time job. There is a clear age pattern in the data: Both young male and female workers are very likely to be in part-time employment (53.5\% and $66.6 \%$ respectively) but there is a stark difference among prime age workers (between 25 and 59 years of age); $10 \%(68 \%)$ of prime age male (female) workers is in part-time employment. Of the women in part-time employment, two thirds work long part-times (between 20 and 34 hours per week), and one third works short part-times (less than 20 hours per week). The high incidence of part-time work appears to be in line with workers' preferences: $80 \%(50 \%)$ of the female (male) part-time workers did not want a full-time job, while only $3.5 \%(6.7 \%)$ of the female (male) part-time workers were in a part-time jobs because they could not find a full-time job. Wil Portegijs et al. (2002) controlling for personal and job characteristics, estimate the Dutch gender wage gap to be about $7 \%$.

${ }_{5}$ The Netherlands has been dubbed the only part-time economy (Richard B. Freeman, 1998). This reflects two aspects of part-time work in the Netherlands: First, its high incidence, and second, the fair treatment it receives. Workers with a part-time job receive the same treatment (pro quota) as their colleagues with a full-time employment contract.

${ }^{6}$ The term "wage" has to be understood as the hourly wage throughout the paper.
} 
We posit that there may be a downside to part-time work because it may adversely affect workers' careers. In fact, human capital accumulation is slow while in part-time employment and if firms use promotions to stimulate human capital accumulation and skill acquisition, the incidence of promotion will be low among workers in part-time employment. In addition, part-time employment may have negative career effects if firms use the number of hours worked as a screening device (Rence M. Landers et al., 1996). Thus, firms' promotion behavior introduces a link between labor market experience and the part-time wage penalty. More to the point, the part-time wage penalty would not arise as young workers enter the labor market, but it would rather develop over time as the effects of foregone promotions due to spells of part-time employment cumulate. ${ }^{7}$

The relationship between career concerns and part-time employment has received little attention thus far, and the development of the part-time wage penalty has never been linked to the interplay between the number of working hours and the incidence of promotion. The focus on the importance of firms' promotion behavior for the part-time wage penalty represents the original contribution of this paper to the literature on part-time employment.

We will proceed in three steps. First, we will investigate the extent of the part-time wage penalty experienced by Dutch workers, the outcome of which will then be contrasted with the part-time wage penalty experienced by young workers (school leavers who, by definition, have very little labor market experience). To do so, we will follow Barry T. Hirsch (2004), who estimated the part-time wage penalty for American workers and who related it to human capital differences (in workers' skills and in occupational skill requirements). ${ }^{8}$ Second, we will investigate the effect of part-time employment on the probability of promotion. Third, we will analyze the importance of part-time employment and promotions for wage growth.

We find that the part-time wage penalty is absent among young school leavers, but that it is well established among more mature workers. We also find that the hours worked, on the whole, do not have a direct impact on wage growth, but that they have a positive effect on the probability of promotion, which is an important source of wage growth.

The structure of the paper is as follows. Section two presents the theoretical underpinnings for the persistence of an equilibrium part-time wage penalty. Section three

\footnotetext{
${ }^{7}$ Kosta G. Mavromaras and Helmut Rudolph (1997) emphasize the importance of discriminatory practices during the hiring process.

${ }^{8}$ However, the similarity with the analysis in Barry T. Hirsch (2004) ends here. Besides using a completely different set of data, the emphasis in our paper is on the analysis of the nexus between part-time employment and promotion probability (and workers mobility). If part-time employment affects workers' careers (through promotions and mobility) it will have long-term effects on workers' wages that would persist even as workers revert to full-time employment.
} 
introduces the data sets used in the empirical analysis. Section four discusses the results of the empirical analysis, and section five offers concluding remarks.

\section{The part-time wage penalty}

\subsection{Demand and supply side perspective}

A part-time wage penalty may characterize the labor market equilibrium only when firms cannot change their mix of part-time and full-time jobs to comply with workers' preferences and thus fail to equalize the wage level across part-time and full-time jobs. This may happen because of worker heterogeneity; part-time and full-time workers are, for some reason, not exchangeable, either because part-time workers have strong preferences about when to work (that may not coincide with employers' preferences about work schedule), or because of the slow human capital accumulation experienced by workers in part-time jobs.

In addition, in the presence of fixed labor costs (such as hiring and training costs) firms may be able to equalize labor costs across part-time and full-time jobs. However, because part-time workers are more expensive than full-time workers, the former must accept lower wages than their full-time colleagues.

There are also factors with the opposite effect, i.e., factors that, in equilibrium, would generate a part-time wage premium. For example, in the presence of a variable product demand characterized by predictable peaks, firms may be willing to pay in order to have the flexibility to absorb them.

The supply side literature focuses on the difference between potential work experience (work experience in full-time employment) and actual work experience (that is adjusted to account for periods out of the labor force and for part-time employment spells). The equilibrium part-time wage gap is then due to differential human capital accumulation during part-time employment spells. This hypothesis is supported by empirical evidence that show very low returns to tenure and labor market experience accumulated during part-time employment spells (compared with the return to experience in full-time employment spells) (Sara Connolly and Mary Gregory, 2004; Barry T. Hirsch, 2004; Alan Manning and Helen Robinson, 2004; Joanna Swaffield, 2000; Sylvia Walby and Wendy Olsen, 2000). Then fulltime and part-time workers cease to be substituted because part-time workers have accumulated significantly less human capital than their full-time colleagues. 


\subsection{Career perspective}

The career perspective entails that the part-time wage penalty would not arise when young workers first enter the labor market, but that it would rather develop in step with workers' career in relation to firms' provision of incentives. For example, firms use promotions to stimulate human capital accumulation or skill acquisition (Robert Gibbons and Michael Waldman, 1999) and if human capital accumulation is fastest in full-time jobs (with respect to part-time ones) the incidence of promotion will be higher among full-time workers than among part-time workers. Over time, as the effects of foregone promotions accumulate, the part-time wage penalty would ensue.

Similarly, an equilibrium part-time wage penalty may also arise if firms use the number of hours worked as a screening device, as in the rat race model (Rence M. Landers, et $a l ., 1996)$. This behavior would also result into a higher incidence of promotion among fulltime workers (with respect to part-time ones).

Furthermore, if part-time workers were more mobile than their full-time colleagues an equilibrium part-time wage penalty could arise in presence of work-life incentives such as the deferred payment scheme implied by an upward sloping earnings - tenure profile (Edward P. Lazear, 1995). In this case, part-time (full-time) workers would be characterized by short (long) tenures, which would place them at the beginning (further to the right) of the upward sloping wage-tenure profile.

Finally, the use of relative compensation schedules to assign promotions (Edward P. Lazear, 1995), such as tournaments, would also result in an equilibrium part-time wage penalty if the measurement of workers' performance was not adjusted for the hours worked or if working hours were to affect performance in a non-linear fashion. In both cases, part-time workers would be outperformed systematically by full-time workers when competing for promotion.

There is evidence, based on US and UK data, of a positive relationship between the number of hours worked and the incidence of promotion (John H. Bishop, 1990; Alison L. Booth et al., 2003; Kristin McCue, 1996). ${ }^{9}$ In particular, Alison L. Booth et al. (2003) find that, in the UK, when part-time jobs are included, male workers turn out to have a higher

\footnotetext{
${ }^{9}$ Notice that male and female workers tend to have the same probability of promotion. John H. Bishop (1990) finds that, in the US, female workers do not have a significantly lower promotion probability, and Alison L. Booth, et al. (2003) find that in the UK male and female workers have the same promotion probability. Furthermore, Kristin McCue (1996) finds that promotions and other changes of positions are an important source of wage growth, that most moves take place in the early stage in the career, but she also finds that male and female workers have the same probability of being promoted. David R. Jones and Gerald H. Makepeace (1996) find that for women's careers personal characteristics are more important than the glass ceiling.
} 
probability of being promoted than their female colleagues. This finding suggests that women's choices for part-time jobs may indeed lower their promotion probability and have long lasting consequences. Linda A. Bell and Richard B. Freeman (2000) argue similarly and find that the number of hours worked has a positive effect on the (perceived) probability of promotion for a sample of German and US workers. This seems to be the case in the Dutch labor market as well. Amelia Roman et al. (2004) find that past part-time employment spells have long-term negative effects on Dutch workers' wages (both males and females), and that these effect are larger for male than for female workers. Notice that part-time employment is almost the rule among Dutch female workers while it is much less frequent among Dutch male employees. ${ }^{10}$ In other words, where long working hours for men is the norm (but less so for women), ${ }^{11}$ the penalty for working part-time can be very high, and the wage penalty would be larger for male (the group affected by the norm) than for female workers (Linda A. Bell and Richard B. Freeman, 2000). ${ }^{12}$

It follows that when workers enter part-time employment (and Dutch women are particularly encouraged to do so) they are likely to incur a long-run career handicap because this choice reduces the likelihood of promotions (Astrid Kunze, 2000). The ensuing wage gap with respect to other workers (typically male colleagues) who did not opt for part-time employment will be permanent and it will not be reversed by a subsequent decision to work full time again. ${ }^{13}$

In the remainder of the paper we will seek empirical evidence to support our conjecture. The empirical analysis consists of three parts. First, we will investigate the extent of the part-time wage penalty proper. Second, we will focus on the relationship between parttime employment and the probability of promotion. Third, we will investigate the effects of promotions and part-time employment on wage growth.

\footnotetext{
${ }^{10}$ The gender wage gap tends to be reduced by the inclusion of the number of working hours among the covariates (Leslie I. Boden and Monica Galizzi, 2003; Lois Joy, 2003).

${ }^{11}$ Maybe inefficiently long (Rence M. Landers et al., 1996).

12 Therefore, the relationship between part-time employment and promotion probability has also consequences for the evolution of the gender wage gap. If female employees have a higher probability of working part-time compared to their male colleagues, the long-run effects of past part-time employment would be compound in the gender wage gap. Therefore, to accurately estimate the gender wage gap from a cross-section of full-time workers, researchers ought to be able to control for past part-time employment (actual labor market experience instead of potential labor market experience).

${ }^{13}$ To be sure, when there is mobility between labor market states is high the focus on full-time workers only may be misleading for two reasons; first, full-time workers at a given moment might have held a part-time job somewhere in the past, second, by focusing on full-time workers important dynamic effects of part-time work may be overlooked.
} 


\section{Data and descriptive analysis}

The data set consists of employer-employee matched data. Firms are sampled and then information about workers within the firms is gathered from administrative records by personnel of the Dutch ministry of Social Affairs and Employment (Piet M. Venema and A. Faas, 1999). The data cover all industries in the economy. We use (pool) two waves of the survey. In the first wave (covering the years 1997-1998, the 1999 wave) 1625 firms are surveyed, and in the second wave (covering the years 1999-2000, the 2001 wave) 1558 firms are surveyed. ${ }^{14}$ The data used in the analysis amount to 62581 workers who did not change employer (43163 males and 19418 females) and 1697 newly hired workers (school leavers, 1007 males and 690 females).

According to the definition applied, workers get promoted when their position within the firm has changed because the level of their job has changed (increased), because there has been a major change in their duties, or because their tasks are now carried out in another department within the same firm.

The data are a panel along two dimensions: Workers are observed twice (in each wave), and multiple workers are observed at any given firm. However, different firms are sampled in both waves. In each wave information about each worker is collected twice, in October 1997 and October 1998, and in October 1999 and October 2000. However, only those workers who stayed with the same employer the year out are observed twice; workers leaving the firm and newly-hired workers are observed only once. Workers who leave the employer are observed only at the beginning of each wave (October 1997 or October 1999); workers who are hired are observed only at the end of each wave (October 1998 or October 2000). We know the previous labor market situation (destination) of newly-hired workers (workers who left the firm), but unfortunately information on their previous (subsequent) wage and job was not recorded.

The data contain information on workers' characteristics relevant for the firm, but the data does not contain any information about workers' household situation or any demographic characteristics apart from age and educational attainment. Therefore, it is impossible to model labor market participation decisions with this set of data. In other words, the data limitations are such that our results should be interpreted as being conditional on the participation

\footnotetext{
${ }^{14}$ The years covered by the two surveys are all years of tight labor market, there are important macroeconomic differences however. During the 1997 and 1998 the Dutch economy have been steadily expanding from 1994 (the year of the latest recession), the Dutch GDP has been growing at a healthy growth rate of about $3.5 \%$, with optimism that would sustain growth for three more years. On the contrary, the year 2000 was a year of exceptionally tight labor market, but it was also the last year of the (seven year long) expansion before the Dutch economy slowed down in 2001 and it finally ground to a still in 2002 .
} 
decision (whether to participate in the labor market). However, the bias introduced is not likely to be large. In fact, $90 \%$ of the workers in our sample did not undergo a change in their working hours but experienced (sometimes consistent) wage changes.

Another particularity of our data relates to the job description, instead of the standard occupation classification, the data set covers the two dimensions of the job description that are relevant for pay and promotion decisions: Job level (nine levels), which includes the autonomy of the decision making and the complexity of the task, the second one is an classification of occupations (seven types), which is similar to the Statistic Netherlands (the CBS) occupational classification (the definitions of job level and type are given in the Appendix 1).

The data are extremely precise with respect to the wage information they contain; along with the gross wage the weekly work hours are recorded and the usual length of the working week at the establishment is also reported. Wages consist of two parts, the base wage, which is linked to job title and occupation (it is the wage definition used in standard wage scale), and a variable wage, which includes overtime payments, compensating differentials (for unpleasant working conditions), performance-related pay, and any other form of incentive pay. Because promotions are usually linked to wage scales, we have chosen to use the base wage as the dependent variable in our analysis. Therefore, the part-time wage penalty must be understood as a lower base wage earned by part-time workers compared to otherwise equal full-time colleagues. Furthermore, we focus on the base wage because the relationship between incentive pay and promotions may blur the results. Should promotion and incentive pay be negatively (positively) correlated, the inclusion of the variable wage part would weaken (reinforce) the part-time wage penalty because workers in part-time jobs would experience less promotions but also higher (lower) incentive pay than their full-time colleagues. Eventually, the negative effect of fewer promotions on the wage could be offset by a higher variable wage component. The list and the definition of the variables used, along with descriptive statistics, can be found in Appendix 2.

Because of the particular Dutch situation where many part-time jobs involve less than 20 working hours, in the empirical analysis we will distinguish between three employment states: small part-time (less than 20 hours per week), part-time (20 hours or more but less than 36 hours per week), and full-time (36 hours or more per week).

The median age of the Dutch female workers who reduced their working time is 32 , while it rises to 37 among women who increased their working time. The data do not contain the information necessary to link the decrease in hours worked to fertility decisions. The 
median age however is consistent with the pattern of fertility among Dutch women. The changes in the hours of work are not the result of measurement error because the wage growth rate among the workers (men and women) who reduced their working time does not differ from the one that characterizes the workers who increased their hours of work. ${ }^{15}$

However, if the decision to work part-time reduces the probability of promotion and promotions are associated with wage growth, part-time employment would still be associated with low wage growth, which would warrant the emergence of a part-time wage penalty in due time. Indeed, the average wage growth among promotees is ten percentage points higher than the average wage growth among their colleagues who are not promoted.

\section{Empirical analysis}

\subsection{Part-time wage penalty}

We use a standard wage equation that includes a quadratic term in age and tenure (tenure is naught among newly hired workers). ${ }^{16}$ Following Yair Mundlak (1978) we account for firm heterogeneity by including the firm's averages of the regressors as shown in equation [1]:

$$
w_{i, h}^{t}=\beta_{1} S M P T_{i, h}^{t}+\beta_{2} P T_{i, h}^{t}+\beta_{3} X_{i, h}^{t}+\beta_{4} Z_{h}^{t}+\beta_{5} Q_{h}^{t}+\varepsilon_{i}^{t}
$$

The superscript $t$ denotes the year (the model is estimated on the data referring to October 1998 and October 2000), the subscript $i$ varies across workers, the subscript $h$ varies across firms, SMPT is a dummy variable equal to 1 if worker $i$ holds a small part-time job (hours $<20), P T$ is dummy variable equal to 1 if worker $i$ holds a part-time job $(20 \leq$ hours $<36)$, $X$ is a vector of other workers and job characteristics, $Z$ is a vector of containing the average worker characteristics calculated for all individuals $i$ belonging to the same firm $h$ (used to control for unobserved firm heterogeneity), and $Q$ is a vector of firm characteristics. ${ }^{17}$ The

\footnotetext{
${ }^{15}$ The effect of measurement error in the hours of work would have been very likely, if a positive wage growth had been found among those workers who reduced their working time and a negative wage growth among those workers who increased their working time (Alan Manning and Helen Robinson, 2004).

${ }^{16}$ All models will be estimated using heteroscedastic robust procedures because of differential wage dispersion across firms.

${ }^{17}$ We refer to the variables included in $X, Z$, and $Q$ as the set of controls. The matrix $X$ includes foreign-born dummy, age (and age squared), tenure (and tenure squared), overtime dummy variable, 5 education dummies, 6 occupation types dummies, 6 occupation level dummies, and the year dummy. The matrix $Q$ includes: 7 firm size dummies, 13 industry dummies, 3 union status dummies, and the length of the working week at the establishment. The $Z$ matrix includes 25 firm averaged variables (including the part-time and small part-time variables), and the constant. The reference group of the variables is given in parenthesis: foreign (Dutch),
} 
parameters $\beta_{1}$ and $\beta_{2}$, if negative, represent estimates of the (small) part-time wage penalty; $\beta_{3}, \beta_{4}$ and $\beta_{5}$ are vectors of parameters to be estimated, and finally $\varepsilon$ is an idiosyncratic error term that follows the usual assumptions. The dependent variable, $w$, is the log of the (base) wage. We estimate equation [1] for male and female workers separately. The results are shown in Table 1, panel A.

\section{TABLE 1 ABOUT HERE}

We find a significant wage penalty for both male and female workers, which decreases in the number of hours worked. The part-time wage penalty is smaller among female workers than among their male colleagues: Male (female) workers in small part-time jobs suffer a wage penalty of about $9.2 \%(2.4 \%)$ in comparison with their full-time male (female) colleagues. Male (female) workers in part-time employment suffer a wage penalty of $6.3 \%$ $(1.7 \%)$ with respect to their male (female) full-time colleagues. ${ }^{18}$

Because unobserved (worker) heterogeneity may influence the decision to work parttime, the estimated wage penalty could in fact represent the cumulative effect of worker heterogeneity and part-time wage penalty. In case of negative correlation (the lesser able are more likely to work part-time), the estimated wage penalty would overstate the true part-time wage penalty. Because worker heterogeneity (the fixed effect) tends to be constant over time, it is likely to have influenced the decision to work part-time the year before. Consequently, following Barry T. Hirsch (2004), we control, albeit imperfectly, for unobserved personal characteristics and accumulated human capital by including two (dummy) variables that capture the (small) part-time employment one year earlier. The estimates are shown in the third and fourth columns in Table 1, panel A. We find that among male workers the small part-time wage penalty is driven to naught when the previous small part-time employment is accounted for. The part-time wage penalty is also substantially reduced but it is still present. Roughly speaking two-fifths of the part-time wage penalty is due to the lagged part-time employment, while three-fifths of it can be ascribed to the current part-time employment. As far as female workers are concerned, we find that the lagged part-time employment variable

education (university and high vocational), occupation: type (creative), occupation: level (management), firm size (1 - 4 employees), industry (culture, sport, and other personal services), and union status (non union). ${ }^{18}$ In the US male (female) workers in small part-time jobs suffer a wage penalty of about $21.3 \%(11 \%)$ with respect to their male (female) full-time colleagues. Male (female) workers in part-time jobs suffer a wage penalty of about 19\% (7.1\%) with respect to their male (female) full-time colleagues (Barry T. Hirsch, 2004). In the UK the part-time wage penalty is of about 22\% (Alan Manning and Helen Robinson, 2004). These estimates of the part-time wage penalty are not directly comparable to ours because our wage concept does not include incentive pay. 
captures the entire wage penalty and the current part-time employment no longer produces a statistically significant effect on the wage. Likewise, the entire wage penalty associated with small part-time jobs is captured by the lagged small part-time variable. ${ }^{19}$

Next, in Table 1 panel B, we turn to the effects of changes in employment status on the wage level earned by workers. Workers who remained in (small) part-time employment face a substantial wage penalty compared to workers employed in full-time jobs in both years. This negative effect found for part-time employment is usually ascribed to low human capital accumulation among part-time workers.

Finally, to bypass the effects of past working experience (and past part-time employment), we focus in the next model on young workers (their average age is about 20 years and so is their median age) entering the labor market just after having left school. ${ }^{20} \mathrm{We}$ estimated equation [1] for this sub-sample of workers. These workers have just joined the firm and therefore their tenure is set equal to zero. Again, we have estimated the model for male and female workers separately. Fertility decisions are relatively far away for this group of workers. Consequently, firms should not treat male and female workers differently. However, the number of hours worked is already different. Women work on average 25 hours per week while male workers work on average 33 hours per week. This suggests that working time decisions are not necessarily related to fertility decision, but they are sometimes made upon entering the labor market. ${ }^{21}$ The results are shown in Table 2.

\section{TABLE 2 ABOUT HERE}

We find that the part-time status does not affect the wage in either group, thus there is no part-time wage penalty among young workers. Not only is the part-time wage penalty statistically not significant, its absolute size is very small too.

Therefore, the part-time wage penalty must arise over time as workers progress in their career. The emergence of the part-time wage penalty over time could be ascribed to the slow

\footnotetext{
${ }^{19}$ There is a great deal of stability in small part-time employment, but much less so in part-time employment. Of the male (female) workers holding small part-time jobs in $(t-1), 89 \%(91 \%)$ had the same position one year later (in $t$ thus). Of the male (female) workers with a part-time job in $(t-1), 33 \%(66 \%)$ were in the same position one year later. The consequence is that the lagged and current small part-time variables could be highly collinear. The very small increase in the $\mathrm{R}^{2}$ due to the introduction of the lagged small part-time variable seems to confirm our suspicion. Collinearity seems to be less of a threat as far as the current and lagged part-time variables are concerned because of the high transition rates between part-time employment and full-time employment.

${ }^{20}$ We cannot control for previous labor market experience. Still, previous labor market experience is not likely to differ among very young workers.

${ }^{21}$ The average age at the first birth is about 27 years. Although, we cannot rule out the possibility that some of the young women in our sub-sample already had children. The very low average age suggests that this is not likely. We cannot elaborate on the fertility issue, however, because of the lack of information about the workers' household composition.
} 
accumulation of human capital while in part-time employment spells (compared to the speed of accumulation that characterizes full-time employment spells). However, these results are also consistent with those demand-side explanations that posit that part-time workers would experience a low incidence of promotion.

\subsection{Part-time employment and promotion probability}

We now turn to the effect of part-time status on the promotion probability (about $5 \%$ of the sample experienced promotions). We will relate promotion (between $t$ and $t-1$ ) to lagged worker characteristics (at $t$-1) using the following (probit) model:

$$
P_{i, h}^{t}=\beta_{1} S M P T_{i, h}^{t-1}+\beta_{2} P T_{i, h}^{t-1}+\beta_{3} X_{i, h}^{t-1}+\beta_{4} Z_{h}^{t-1}+\beta_{5} Q_{h}^{t-1}+\varepsilon_{i, h}^{t}
$$

Where $P$ is a dummy variable equal to one if workers $i$ in firm $h$ experience a promotion between $t$ and $t-1$ and zero elsewhere. The remaining symbols retain their meaning.

The results are shown in Table 3. The negative relationship between the part-time employment dummies and the promotion probability stands out clearly. Male and female workers in part-time employment experience a lower incidence of promotion. This is even more so for workers (both male and female) with a small part-time job, and it is particularly strong for the male workers among them.

\section{TABLE 3 ABOUT HERE}

We do not detect gender differences in the promotion probability, viz. male and female workers are characterized by the same incidence of promotion.

The differential incidence of promotion among part-time and full-time workers is not enough to sustain an equilibrium part-time wage penalty. To do so, it must be that promotions accelerate wage growth.

\subsection{Part-time employment, promotions and wage growth}

To investigate the relationship between part-time employment, promotions and wage growth, we follow the methodology in Alison L. Booth, et al. (2003), and after having established the effect of part-time employment on the probability of promotion, we turn to the effects of promotion and part-time employment on wage growth. To this end, we relate the 
wage growth (the difference is the log wage) to a set of workers and firm characteristics and to promotions (all symbols retain their meaning):

$$
w_{i, h}^{t}-w_{i, h}^{t-1}=\beta_{1} S M P T_{i, h}^{t-1}+\beta_{2} P T_{i, h}^{t-1}+\beta_{3} X_{i, h}^{t-1}+\beta_{4} Z_{h}^{t-1}+\beta_{5} Q_{h}^{t-1}+\varepsilon_{i, h}^{t}
$$

To gauge the effect of promotions on wage growth we also estimate a second version of equation [3] that includes a promotion dummy $(P)$ among the regressors (Alison L. Booth et al., 2003). The results are shown in Table 4, panel A.

\section{TABLE 4 ABOUT HERE}

We find that, for both male and female workers, the number of hours worked does not have a significant effect on wage growth; still promotions are a very important source of wage growth, which can account for an increase in the wage growth rate of about eight percentage points (the effect of promotions on wage growth is the same among male and female workers). Moreover, once promotions are accounted for, we find a positive influence of (initial) part-time employment on the wage growth rate. In Table 4 panel B, it can be seen that this positive effect is due to wage growth accelerations that can be ascribed to the transition from part-time to full-time jobs among male workers, while among female workers there appears to be a part-time premium in wage growth (male workers experience a small, but significant, part-time wage growth penalty). All in all, our results suggest that the number of hours worked does not affect the wage growth directly, but does so indirectly through the effect of the number of hours worked on the likelihood of promotion.

\subsection{Synthesis}

We can summarize our results thus far as follows. Consistent with the widening of the part-time wage penalty as labor market experience accumulates, we find that workers (of both genders) forego promotion possibilities during part-time employment spells and consequently miss important wage growth accelerations. ${ }^{22}$

The larger part-time wage penalty experienced by male workers relative to female workers still remains to be explained. We offer two explanations for this phenomenon. The

\footnotetext{
${ }^{22}$ Audrey Light and Manuelita Ureta (1995) using US data, find a substantial wage penalty for time out of the labor market for male and female workers in the early stages of their careers. The same result is found among German pupils spending different amounts of time in the apprenticeship system (Astrid Kunze, 2002).
} 
first one posits that female workers switch more often between part-time and full-time jobs than male workers. Consequently, most female workers would spend at least some of their time on the labor market in part-time employment. In contrast, male workers tend to be stuck in one form of employment with little opportunity of change, full-time workers tend to work full-time for their entire working life and workers holding small part-time jobs tend to hold them throughout. In this scenario the female part-time wage penalty would be smaller than the male part-time wage penalty, even if male and female workers would have the same promotion probability. This could be a Dutch phenomenon, Amelia Roman et al. (2004), using the OSA panel, show that during the 1990 s $24 \%-29 \%$ (6\%) of Dutch female (male) workers held a part-time position in the three years prior to the interview. Moreover, Ruud Muffels et al. (1998), using the Dutch Socioeconomic Panel, show that in the early 1990s $22 \%$ of female workers with a full-time job switched to a part-time job within the following four years.

The second explanation we offer relies on the differential salience of part-time employment among male and female workers induced by the popularity of part-time employment among female workers. If most women choose to work part-time (and Dutch women are encouraged to do so), part-time employment status cannot be used as a screening device because it ceases to be informative about work attitudes. On the contrary, because parttime employment is still rather uncommon among male workers, it becomes salient when chosen by male workers. It follows that part-time employment can now be used as a screening device. If male part-time workers are adversely affected by firms' screening behavior (but female part-time workers are not), it follows that male workers would be characterized by a larger part-time wage penalty relative to female workers.

\section{Conclusion}

In this paper we have investigated the part-time wage penalty in the Netherlands. The wage penalty is usually ascribed to the differential rate of human capital accumulation during part-time and full-time employment spells. The original element in our analysis is represented by the revelation of an alternative channel that would lead to the emergence of a part-time wage penalty: the nexus between part-time employment and the promotion probability. In this framework part-time employment bears a wage penalty, because, inter alia, the incidence of promotion is low among part-time workers and promotions are an important source of wage growth. The negative association between part-time employment and the incidence of promotion arises when firms use promotions to stimulate skill acquisition and human capital 
accumulation, or base their work incentive schemes on performance measures that are affected by the number of hours worked, or use screening mechanisms that are affected by the number of hours worked.

Consistent with this view, we have found that part-time workers do have a lower promotion probability and that promotions are accompanied by a wage growth acceleration of about eight percentage points. We have also found that the part-time wage penalty is larger for male than for female workers, and that it does not arise at onset when workers enter the labor market but it rather develops over time as labor market experience accumulates.

The negative association between part-time employment and promotions is a rather important relationship for countries like the Netherlands where the use of part-time employment is widespread, because it implies that part-time jobs tend to offer limited career possibilities. 


\section{Appendix 1: Variable List and Descriptive Statistics}

\section{TABLE A1 ABOUT HERE}

\section{Appendix 2: Occupational Level and Job Type}

Occupational Levels

Level Description

Level I: $\quad$ Very simple and repeated tasks, which do not require any particular education or experience, and are carried out under direct supervision.

Level II: $\quad$ Simple and repeated tasks, which require some basic administrative or technical knowledge or some working experience. Some autonomy is required, but the tasks are carried out under supervision.

Level III (low): $\quad$ Less simple tasks, of a repetitive nature, which require low administrative or technical knowledge or some working experience. The tasks involve a degree of autonomy.

Level III (high): $\quad$ Less simple tasks, of different natures, which require low administrative or technical knowledge with completed vocational education in a given technique or profession. The tasks involve a degree of autonomy.

Level IV: $\quad$ Difficult tasks, of many different natures, which require an intermediate level of administrative or technical knowledge and a high level of autonomy.

Level V: $\quad$ Composite tasks within an occupation, which require a high level of administrative or technical knowledge and a high level of autonomy.

Level VI: $\quad$ Directive and managerial tasks, which require analytical, creative and personal communication skills. Tasks carried out on the basis of autonomous decision-making and require an academic education.

Level VII: $\quad$ Management (CEO) of mid-size firms and participation in the strategic decision-making.

Level VIII: $\quad$ CEO of large firms (not included in the analysis for confidentiality reasons).

Job Type and Occupational Classification

Job Type

CBS one-digit and two-digits Occupational codes

Production

$$
6,7
$$

Administrative 3

Information Technology

Commercial

083 and 084

Services

4

Creative

Managerial

0 (excluded 083 and 084) 


\section{References}

Bell, Linda A. and Freeman, Richard B. "The Incentive for Working Hard: Explaining Hours Worked Differences in the U.S. And Germany", 2000,

Bishop, John H. "Job Performance, Turnover, and Wage Growth." Journal of Labor Economics, 1990, 8(3), pp. 363-86.

Blau, Francine D. "Trends in the Well-Being of American Women, 1970 - 1995." Journal of Economic Literature, 1998, 36, pp. 112-65.

Blau, Francine D. and Kahn, Lawrence M. "Swimming Upstream: Trends in the Gender Wage Differential in the 1980s." Journal of Labor Economics, 1997, 15(1), pp. 1-42. . "Understanding International Differences in the Gender Wage Gap." Journal of Labor Economics, 2003, 21(1), pp. 106-44.

Boden, Leslie I. and Galizzi, Monica. "Income Losses of Women and Men Injured at Work." The Journal of Human Resources, 2003, 38(3), pp. 722 - 57.

Booth, Alison L.; Francesconi, Marco and Frank, Jeff. "A Sticky Floors Model of Promotion, Pay, and Gender." European Economic Review, 2003, 47, pp. 295-322.

Connolly, Sara and Gregory, Mary. "Part-Time Employment and Long-Term Career Prospects: The New Labour Market Segmentation", 2004, University of East Anglia, School of Economics and Social Studies, Mimeo.

Euwals, Rob and Hogerbrugge, Maurice. "Explaining the Growth of Part-Time Employment: Factors of Supply and Demand", 2004, IZA Discussion Paper, No 1124. Freeman, Richard B. "War of Models: Which Labor Market Institutions for the 21st Century?" Labour Economics, 1998, 5, pp. 1-24.

Gibbons, Robert and Waldman, Michael. "Careers in Organizations: Theory and Evidence," O. A. Ashenfelter and D. Card, Handbook of Labor Economics. Amsterdam: Elsevier Science, 1999, 2439 - 83.

Goldin, Claudia D. "Career and Family: College Women Look to the Past," F. D. Blau and R. G. Ehrenberg, Gender and Family Issues in the Workplace. New York: Russel Sage Foundation, 1997,

Hirsch, Barry T. "Why Do Part-Time Workers Earn Less? The Role of Worker and Job Skills", 2004, IZA Discussion Paper, No 1261.

Jones, David R. and Makepeace, Gerald H. "Equal Worth, Equal Opportunities: Pay and Promotion in an Internal Labour Market." Economic Journal, 1996, 106, pp. 401-09.

Joy, Lois. "Salaries of Recent Male and Female College Graduates: Educational and Labor Market Effects." Industrial and Labor Relations Review, 2003, 56(4), pp. 606-21.

Kunze, Astrid. "The Determinant of Wages and the Gender Wage Gap", 2000, . "The Evolution of the Early Career Gender Wage Gap", 2002,

Landers, Rence M.; Rebitzer, James B. and Taylor, Lowell J. "Rat Race Redux: Adverse Selection in the Determination of Work Hours in Law Firms." American Economic Review, 1996, 86(3), pp. 329 - 48.

Lazear, Edward P. Personnel Economics. Cambridge, Massachusetts: The MIT Press, 1995. Light, Audrey and Ureta, Manuelita. "Early-Career Work Experience and Gender Wage Differentials." Journal of Labor Economics, 1995, 13(1), pp. 121-54.

Lundberg, Shelly J. and Startz, Richard. "Private Discrimination and Social Intervention in Competitive Labor Market." American Economic Review, 1983, 73(3), pp. 340-47.

Manning, Alan and Robinson, Helen. "Something in the Way She Moves: A Fresh Look at an Old Gap." Oxford Economic Papers, 2004, 56, pp. 168 - 88.

Mavromaras, Kosta G. and Rudolph, Helmut. "Wage Discrimination in the Reemployment Process." The Journal of Human Resources, 1997, 32(4), pp. 812 - 60. 
McCue, Kristin. "Promotions and Wage Growth." Journal of Labor Economics, 1996, 14(2), pp. 175 - 209.

Muffels, Ruud; Dekker, Ronald and Stancanelli, Elena G.F. "Flexible and Permanent Jobs on the External Labour Market: Empirical Anlyses of Labour Market Mobility Patterns Using Panel Data", 1998, Netherlands School for Social and Economic Policy Research, Research Paper, 99/02.

Mundlak, Yair. "On the Pooling of Time Series and Cross Section Data." Econometrica, 1978, 46, pp. 69 - 85.

OECD. Employment Outlook. Paris: OECD, 2002. . Employment Outlook. Paris: OECD, 2001.

Portegijs, Wil; Boelens, Annemarie and Keuzenkamp, Saskia. Emancipatie Monitor. Den Haag: Sociaal en Cultureel Planbureau, 2002.

Roman, Amelia; Fouarge, Didier and Luijkx, Ruud. "Career Consequences of Part-Time Work: Results from Dutch Panel Data 1990-2001", 2004, OSA Publicatie, A 206.

Schettkat, Ronald and Yocarini, Lara. "Education Driving the Rise in Dutch Female Employment. Explanations for the Increase in Part-Time and Female Employment in the Netherlands, Contrasted with Germany", 2001,

Swaffield, Joanna. "Gender, Motivation, Experience and Wages", 2000, LSE, CEP Discussion Paper.

Venema, Piet M. and Faas, A. Arbeidsvoorwaardenontwikkelingen in 1998 Een Onderzoek Van De Arbeidsinspectie Naar Gerealiseerde Loonontwikkelingen, Extra Uitkeringen En Afdrachtverminderingen. The Hague: Dutch Ministry of Social Affairs and Employment, 1999.

Walby, Sylvia and Olsen, Wendy. "The Uk Gender Wage Gap and Gendered Work Histories", 2000, Paper Presented to the conference of the British Household Panel Survey, Institute for Social and Economic Research, University of Essex. 
Table 1: Effect of the number of hours worked on the hourly wage. OLS, robust standard errors in parentheses (*: significant at $5 \%$ level).

\section{dependent variable: Log Hourly}

Wage

\begin{tabular}{|c|c|c|c|c|c|c|c|}
\hline \multirow{3}{*}{$\begin{array}{l}\text { A } \\
\text { Hours Worked } \\
\text { small part-time }(<20 \text { hours })\end{array}$} & Males & & Females & & Males & & Females \\
\hline & & & & & & & \\
\hline & $\begin{array}{l}-0.092 \\
(0.019)\end{array}$ & $*$ & $\begin{array}{c}-0.024 \\
(0.006)\end{array}$ & $*$ & $\begin{array}{l}-0.012 \\
(0.024)\end{array}$ & & $\begin{array}{c}0.020 \\
(0.009)\end{array}$ \\
\hline part-time $(20 \leq$ hours $<36)$ & $\begin{array}{l}-0.063 \\
(0.012)\end{array}$ & $*$ & $\begin{array}{c}-0.017 \\
(0.004)\end{array}$ & $*$ & $\begin{array}{c}-0.039 \\
(0.015)\end{array}$ & $*$ & $\begin{array}{c}0.003 \\
(0.006)\end{array}$ \\
\hline small part-time (lagged) & - & & - & & $\begin{array}{l}-0.090 \\
(0.025)\end{array}$ & $*$ & $\begin{array}{l}-0.057 \\
(0.010)\end{array}$ \\
\hline part-time (lagged) & - & & - & & $\begin{array}{l}-0.026 \\
(0.014)\end{array}$ & & $\begin{array}{l}-0.027 \\
(0.006)\end{array}$ \\
\hline set of controls & Yes & & Yes & & Yes & & Yes \\
\hline Number of observations & 43163 & & 19418 & & 43163 & & 19418 \\
\hline R-squared & 0.9134 & & 0.9380 & & 0.9135 & & 0.9382 \\
\hline
\end{tabular}

Reference groups: full-time and full-time lagged

\begin{tabular}{|c|c|c|c|}
\hline $\mathbf{B}$ & Males & & Females \\
\hline \multicolumn{4}{|l|}{ Transitions } \\
\hline part-time - full-time & $\begin{array}{l}-0.019 \\
(0.015)\end{array}$ & & $\begin{array}{l}-0.025 \\
(0.006)\end{array}$ \\
\hline small part-time - full-time & $\begin{array}{c}-0.148 \\
(0.044)\end{array}$ & $*$ & $\begin{array}{l}-0.035 \\
(0.025)\end{array}$ \\
\hline part-time - part-time & $\begin{array}{l}-0.072 \\
(0.012)\end{array}$ & $*$ & $\begin{array}{l}-0.023 \\
(0.005)\end{array}$ \\
\hline small part-time - part-time & $\begin{array}{l}-0.159 \\
(0.037)\end{array}$ & $*$ & $\begin{array}{l}-0.060 \\
(0.011)\end{array}$ \\
\hline full-time - part-time & $\begin{array}{c}0.036 \\
(0.039)\end{array}$ & & $\begin{array}{c}0.022 \\
(0.011)\end{array}$ \\
\hline small part-time - small part-time & $\begin{array}{l}-0.096 \\
(0.021)\end{array}$ & $*$ & $\begin{array}{l}-0.035 \\
(0.007)\end{array}$ \\
\hline part-time - small part-time & $\begin{array}{l}-0.111 \\
(0.032)\end{array}$ & $*$ & $\begin{array}{l}-0.008 \\
(0.013)\end{array}$ \\
\hline full-time - small-part-time & $\begin{array}{l}-0.055 \\
(0.047)\end{array}$ & & $\begin{array}{c}0.017 \\
(0.024)\end{array}$ \\
\hline set of controls & Yes & & Yes \\
\hline Number of observations & 43163 & & 19418 \\
\hline R-squared & 0.9135 & & 0.9382 \\
\hline
\end{tabular}

Reference group: full-time - full-time 
Table 2: Effect of the number of hours worked on the hourly wage among school leavers. OLS, robust standard errors in parentheses (*: significant at $5 \%$ level).

dependent variable: Log Hourly Wage

Hours Worked

small part-time $(<20$ hours $)$

Males $\quad$ Females

part-time $(20 \leq$ hours $<36)$

$-0.011$

$(0.050) \quad(0.031)$

$-0.016 \quad 0.003$

$(0.041) \quad(0.032)$

set of controls

Yes Yes

Number of observations $\quad 1007 \quad 690$

$\begin{array}{lll}\text { R-squared } & 0.89 & 0.93\end{array}$

Reference group: full-time 
Table 3: Effect of the number of hours worked on the promotion probability. Probit, robust standard errors in parentheses (*: significant at $5 \%$ level).

dependent variable: dummy variable $=1$ if promotion;

0 elsewhere

\section{Hours Worked}

small part-time $(<20$ hours $)$

part-time $(20 \leq$ hours $<36)$

set of controls

Observations

Loglikelihood Reference Model

Loglikelihood Full Model

Reference group: full-time

\begin{tabular}{cccc} 
Males & & Females & \\
-0.505 & $*$ & -0.380 \\
$(0.118)$ & & $(0.066)$ & \\
-0.165 & $*$ & -0.156 & $*$ \\
$(0.063)$ & & $(0.043)$ & \\
Yes & \multicolumn{2}{c}{ Yes } & \\
& & & \\
43163 & & 19418 & \\
-8720.532 & -3615.954 \\
-7910.779 & -3181.325
\end{tabular}

Males Females

$(0.118) \quad(0.066)$

$-0.165 *-0.156 *$ 
Table 4: The effect of internal mobility on wage growth. OLS, robust standard errors in parentheses (*: significant at $5 \%$ level).

dependent variable:

log hourly wage (t) - log hourly wage (t-1)

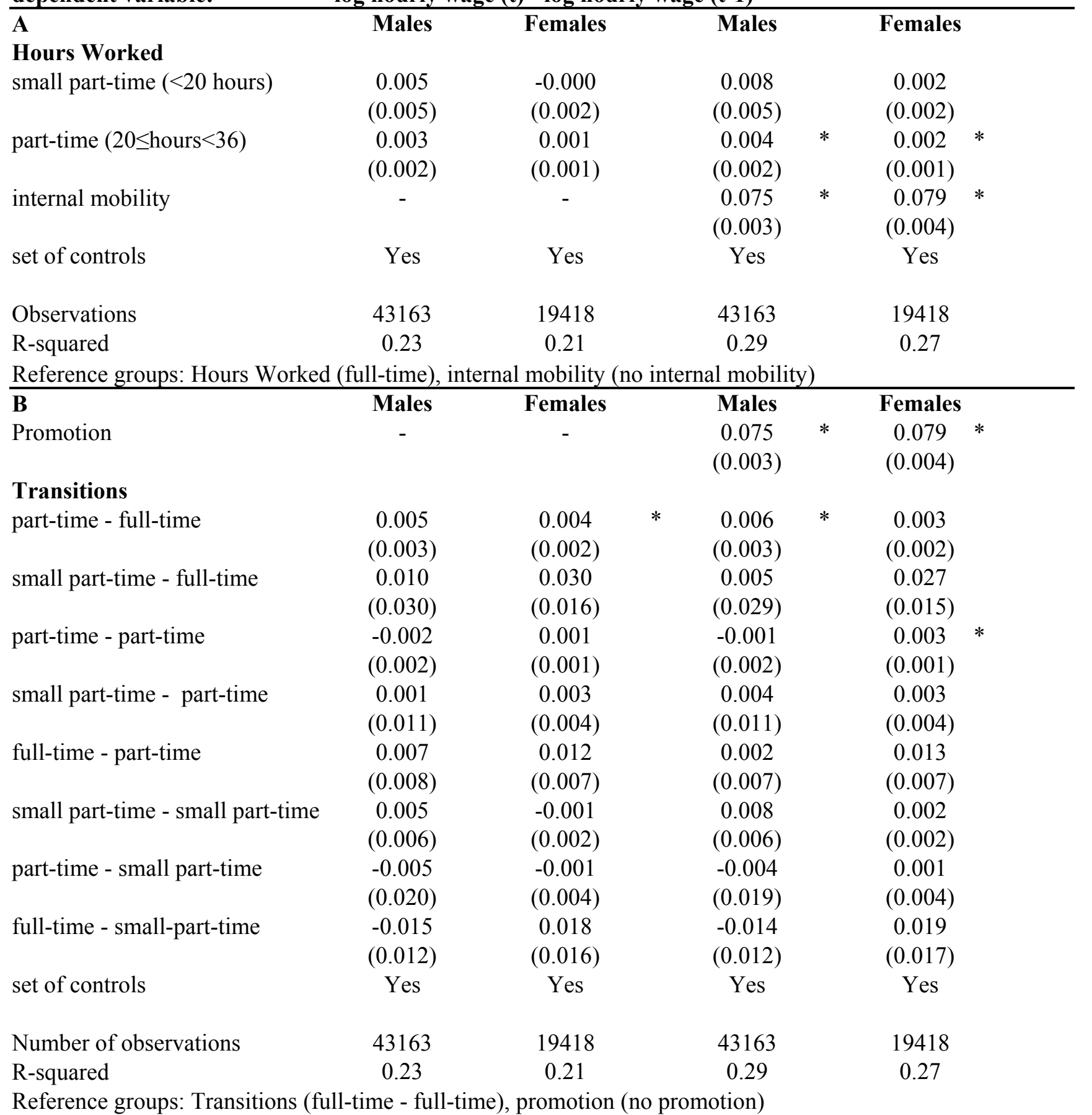




\section{Table A1: Descriptive statistics.}

Variable

hours

small part-time

part-time

full-time

foreign

age

tenure

primary

low general

low vocational

secondary general

secondary vocational

university

technical

administrative

information technology

commercial

services

management

creative

very simple tasks

simple and repetitive tasks

Definition

hours worked in the week (log)

hours worked in the week $<20$

$20 \leq$ hours worked in the week $<36$

hours worked in the week $\geq 36$

foreign worker (non Dutch)

worker's age

years with current employer

basis education (LO)

first level general education (MAVO)

first level vocational education (MBO)

secondary school diploma (HAVO, VWO)

advanced vocational education (HABO)

university (WO)

technical occupation (see Appendix 2)

administrative occupation (see Appendix 2)

IT occupation (see Appendix 2)

commercial occupation

service occupation (see Appendix 2)

management (see Appendix 2)

creative occupation (see Appendix 2)

Level I (see Appendix 2)

Level II (see Appendix 2)

Level III low (see Appendix 2)

non routine, with simple decision making Level III high (see Appendix 2)

difficult tasks, decision making

difficult tasks, initiative

management

upper management
$1-4$
$5-9$
$10-19$
$20-49$
$50-99$

Level IV (see Appendix 2)

Level V (see Appendix 2)

Level VI (see Appendix 2)

Level VII (see Appendix 2)

fewer than 5 employees at the firm

5 - 9 employees at the firm

10 - 19 employees at the firm

20 - 49 employees at the firm

50 - 99 employees at the firm dummy variable

dummy variable

dummy variable

dummy variable

dummy variable

dummy variable

dummy variable

dummy variable

dummy variable

dummy variable

dummy variable

dummy variable

dummy variable

dummy variable

dummy variable

dummy variable

dummy variable

dummy variable

dummy variable

dummy variable

dummy variable

dummy variable

dummy variable

dummy variable

dummy variable

dummy variable

dummy variable

dummy variable

dummy variable

dummy variable
Females

mean std. err.

$3.21 \quad 0.56$

$0.25 \quad 0.43$

$0.25 \quad 0.43$

$0.51 \quad 0.50$

$0.05 \quad 0.21$

$37.30 \quad 10.31$

$7.61 \quad 6.84$

$0.07 \quad 0.25$

$0.19 \quad 0.39$

$0.22 \quad 0.41$

$0.14 \quad 0.35$

$0.25 \quad 0.43$

$0.10 \quad 0.31$

$0.11 \quad 0.31$

$0.31 \quad 0.46$

$0.01 \quad 0.10$

$0.12 \quad 0.32$

$0.41 \quad 0.49$

$0.04 \quad 0.19$

$0.02 \quad 0.13$

$0.05 \quad 0.22$

$0.12 \quad 0.33$

$0.25 \quad 0.43$

$0.20 \quad 0.40$

$0.27 \quad 0.44$

$0.09 \quad 0.28$

$0.02 \quad 0.14$

$0.00 \quad 0.02$

$0.02 \quad 0.15$

$0.05 \quad 0.22$

$0.08 \quad 0.28$

$0.11 \quad 0.32$

$0.14 \quad 0.35$ 
Table A1: Continued.

$100-199$

$200-499$

$=>500$

agriculture

mining

manufacturing

public utilities

construction

wholesale \& retail trade

restaurants \& hotels

transport \& communication

financial services

business services

public administration

education

health services

culture, sport, \& other personal services

Industry Collective Agreement

Firm Collective Agreement

AVV

non union

length of the working week

hourly wage

promotion

overtime

number of observations
100 - 199 employees at the firm

200 - 499 employees at the firm

500 or more employees at the firm

dummy variable

dummy variable

dummy variable

dummy variable

dummy variable

dummy variable

dummy variable

dummy variable

dummy variable

dummy variable

dummy variable

dummy variable

dummy variable

dummy variable

dummy variable

dummy variable

dummy variable

dummy variable

dummy variable

dummy variable

dummy variable

not covered by any union agreement

the firm, in log)

gross wage (without overtime or bonuses) devided

by the number of hours worked

dummy variable

dummy variable

$\begin{array}{rrrr}0.20 & 0.40 & 0.17 & 0.37 \\ 0.18 & 0.38 & 0.19 & 0.39 \\ 0.20 & 0.40 & 0.23 & 0.42 \\ 0.01 & 0.12 & 0.01 & 0.09 \\ 0.01 & 0.10 & 0.00 & 0.07 \\ 0.34 & 0.47 & 0.18 & 0.38 \\ 0.03 & 0.16 & 0.01 & 0.10 \\ 0.09 & 0.29 & 0.01 & 0.10 \\ 0.14 & 0.35 & 0.15 & 0.36 \\ 0.01 & 0.10 & 0.02 & 0.15 \\ 0.09 & 0.28 & 0.05 & 0.22 \\ 0.03 & 0.17 & 0.05 & 0.22 \\ 0.11 & 0.31 & 0.13 & 0.33 \\ 0.07 & 0.25 & 0.07 & 0.25 \\ 0.01 & 0.09 & 0.01 & 0.10 \\ 0.03 & 0.17 & 0.24 & 0.42 \\ 0.03 & 0.18 & 0.07 & 0.26 \\ 0.72 & 0.45 & 0.73 & 0.45 \\ 0.07 & 0.25 & 0.04 & 0.20 \\ 0.03 & 0.16 & 0.03 & 0.17 \\ 0.00 & 0.04 & 0.00 & 0.06 \\ 38.61 & 1.67 & 37.80 & 1.73 \\ 4.12 & 0.79 & 3.90 & 0.77 \\ 0.05 & 0.22 & & \\ 0.24 & 0.43 & 0.05 & 0.21 \\ 43163 & & 0.09 & 0.29 \\ & & & \end{array}$

